\title{
Modifying Merger Consent Decrees to Improve Merger Enforcement Policy
}

Steven C. Salop

Georgetown University Law Center, salop@law.georgetown.edu

This paper can be downloaded free of charge from:

https://scholarship.law.georgetown.edu/facpub/1674

http://ssrn.com/abstract=2768143

Steven C. Salop, Modifying Merger Consent Decrees to Improve Merger Enforcement Policy, Antitrust, Fall 2016, at 15-20

This open-access article is brought to you by the Georgetown Law Library. Posted with permission of the author. Follow this and additional works at: https://scholarship.law.georgetown.edu/facpub

Part of the Antitrust and Trade Regulation Commons, and the Banking and Finance Law Commons 


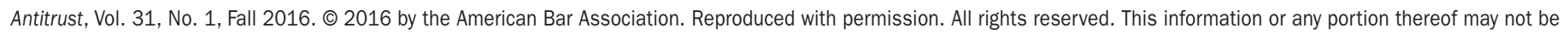

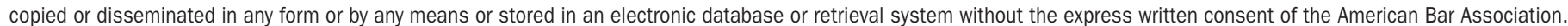

\section{Modifying Merger Consent Decrees to Improve Merger Enforcement Policy}

BY STEVEN C. SALOP

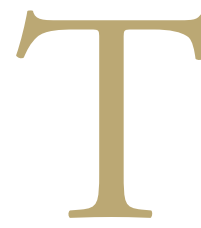

HIS ARTICLE ANALYZES MY short proposal for reviewing and modifying merger consent decrees to permit additional relief if the provisions of the initial consent merger are found to fail to preserve or restore competition in a reasonable period of time after the merger was consummated. ${ }^{1}$ My proposal also would involve more frequent reviews of consummated mergers that have been cleared without challenge, particularly those that were close calls. While "Don't Look Back" might be the best anthem for artists, economic decision theory would not support that approach to merger policy. ${ }^{2}$

Predicting the impact of proposed mergers and remedies on consumers is difficult. As a result, remedies sometimes turn out to be insufficient to protect consumers and competition. This review and modification process would help to correct insufficient, poorly designed, or otherwise ineffective consent decrees. It will place more of the risk of failure on the merging parties who claim to the agency that the merger would not harm competition and that the remedy is sufficient to cure the agency's concerns. As a result, the merging firms likely would be incentivized to provide more efficient and effective remedies at the HSR stage, rather than bear the risk of less efficient remedies, disgorgement and other relief later. This allocation of risk to the merged firm also would help to deter the post-merger exercise of market power achieved or enhanced by the merger. For the same reasons, it also would increase the deterrence of anticompetitive mergers. Finally, it also could reduce the moral hazard of overreaching argumentation by the merging parties and their attorneys.

Review of consummated mergers is neither novel nor new. While HSR has involved pre-merger notification for the past 40 years, it did not eliminate the ability of the agencies to issue complaints against consummated mergers. The agencies occasionally do bring enforcement actions for con-

Steven Salop is Professor of Economics and Law, Georgetown University Law Center, and Senior Consultant, Charles River Associates. The views in this article are the author's and are not necessarily shared by his colleagues at Georgetown or CRA, or by any clients for whom he has provided economic consulting. summated transactions after several years. Perhaps the most notable recent example is the action brought in 2004 against Evanston Northwestern Healthcare about four years after the transaction closed without challenge. ${ }^{3}$ The FTC's hospital merger retrospectives studies apparently began sometime after August 2002. ${ }^{4}$ There have also been cases where complaints were issued immediately after a merger was consummated, including Bazaarvoice, ${ }^{5}$ Heraeus Electro-Nite, ${ }^{6}$ and Chicago Bridge?

While these matters involved transactions that previously either were not notified or not challenged under HSR, postmerger review and modification provisions also should be included as a matter of course for mergers that are challenged and settled with consent decrees. ${ }^{8}$ Proposals for such postmerger reviews also are not new. In his 1998 article, Brian Facey took a decision-theory approach in proposing postmerger review of efficiencies. ${ }^{9}$ He pointed out that Professor Joseph Brodley made a proposal for post-merger reviews a decade earlier. ${ }^{10}$ The FTC also contemplated a post-merger review in the Lilly/PCS vertical merger. As described by FTC Chairman Robert Pitofsky in a 1995 speech, the FTC's statement said that "[i]f subsequent developments indicate anticompetitive effects, despite the presence of the negotiated order, the Commission commits itself to seek other relief including, if necessary, post-acquisition divestiture." ${ }^{11}$ Facey also cited a Pennsylvania hospital case that contained a "put up or shut up" consent decree requiring "efficiency shortfall to be paid to the Attorney General's office after 5-year trial period." 12

However, the type of consent decree review process outlined here has not become the norm.

\section{The Goals and Benefits of the Review and Modification Proposal}

There are two general goals served by antitrust sanctions, which can be called "ex ante" and "ex post" goals. The ex ante goal is to deter initial conduct that would lead to the need for ex post relief. If deterrence works perfectly, of course, there will be no need for the ex post remedy. In cases where deterrence fails, the ex post goal is to prevent future harms. Interestingly, ex post remedial inefficiency that can arise from delaying relief is a two-edged sword. A higher cost ex post remedy actually can incentivize more efficient ex ante behav- 
ior. Those extra costs should incentivize the merging firms to avoid proposing ineffective remedies during the premerger process or exercising market power caused by the merger. In this way, the post-merger review and modification process acts as a partial guarantee by the merging firms.

These two general goals suggest three specific benefits of the review and modification proposal: (1) to remedy ineffective consent decrees in order to preserve and restore competition; (2) to facilitate the adoption of more effective remedies during the HSR process; and (3) to deter anticompetitive mergers and the exercise of market power achieved from mergers.

First, the review and modification process can provide an important backstop process for divestitures that fail from (say) bankruptcy of the divestee or unethical behavior by the divesting firm that does not violate the decree The well-known bankruptcies in the Hertz/Dollar Thrifty ${ }^{13}$ and Albertsons/ Safeway ${ }^{14}$ divestitures are two recent examples.

Second, these reviews and potential modifications can provide a backstop where the assumptions underlying the relief in the initial consent decree turn out to have been incorrect or where the relief turns out to be insufficient to preserve competition and protect consumer welfare. Firms already have the right to petition for relief from consent decrees when conditions in the market have changed. This proposal creates symmetry.

This backstop is needed, given the record of current merger policy. For example, John Kwoka has reported on his research on merger retrospectives. In his 2013 article, his database had 46 true mergers, for which 38 ( 83 percent) had price increases averaging almost 10 percent, whereas the other 8 had average decreases averaging almost 5 percent, implying significantly higher prices on balance..$^{15}$ In his 2015 book, Kwoka had a larger sample of transactions. ${ }^{16}$ Robert Skitol's review of Kwoka's book highlighted and quoted the following highly "provocative" results: ${ }^{17}$

- "At the product level, the average outcome for all 119 observations on postmerger prices is an increase of 4.3 percent ... . . More than 60 percent of product price changes show increases, and those increases average nearly 9 percent.... Of all mergers that resulted in price increases, the agencies acted in only 38 percent of cases, suggesting substantial under-enforcement. Incorrectly cleared mergers on average resulted in price increases in excess of 10 percent." 18

- "For all cases in which the agencies challenged mergers, the outcome was ... an average price increase of 7.71 percent, indicating incorrect determinations or ineffective remedies to the mergers." 19

n "[D]ivestiture remedies are associated with price increases of 6.11 percent," casting doubt on their adequacy. "Conduct remedies result in price increases of 12.81 percent, suggesting that these are largely ineffective in restraining postmerger price increases." 20

- While less frequently studied, "the nonprice effects of mergers generally mirror the measured price effects. Anti- competitive price increases tend to be accompanied by reductions in quantity, quality, and $\mathrm{R} \& \mathrm{D} .{ }^{21}$

While these studies do not indicate that all mergers lead to higher prices, they do indicate a weakness in merger enforcement policy. ${ }^{22}$

These harms are not surprising in light of the agencies' current apparently limited remedial goals. The goal of preserving competition is often considered to mean that a remedy (say, a divestiture) should be limited to just enough to prevent harms from the merger, not to strictly benefit consumers, relative to the absence of the merger. ${ }^{23}$ With this limited goal, consumers would be expected on average to obtain zero net benefits from settled mergers.

Suppose that the parties instead reject the settlement demand, in which case the transaction is abandoned or litigation ensues. If the transaction is abandoned or if the case goes to court and the agency successfully secures a court injunction, there would be neither benefits nor harms. But, if the agency loses its challenge, and the decision is a false negative, then consumers are made worse off. Thus, if the agency's expectations were accurate, then overall consumer welfare would be harmed on balance from the entire universe of challenged mergers. Consumers also would be harmed from mergers where the agency accepts a somewhat weaker divestiture (i.e., accepting some consumer harm) in order to avoid the greater possible harm from losing its challenge in court.

Third, the proposal also can have beneficial effects on the incentives of the merging parties, both before and after the merger. During the pre-merger process, the merging parties and their attorneys might be deterred from over-claiming, once they recognize that their claims about large efficiencies, easy entry, big buyers, or other reasons for lack of potential market power harms might be later reviewed and evaluated. Their incentives to propose flawed remedies similarly would be reduced, knowing that the remedial failure would lead to further relief. The fact that future remedies may be more costly could provide a further incentive to solve the problems before the merger. After the merger is consummated, the merged firm also may be deterred from exercising market power gained from the merger out of fear that this conduct will lead to demands for further relief. Finally, the proposal might deter some anticompetitive mergers, in that the likely private benefits from such mergers would be reduced.

Finally, while this post-merger review and consent decree modification process is designed to complement pre-merger relief, in principle it might permit the agencies to demand smaller divestitures or other relief in certain cases, knowing that there can be further adjustments later, if needed. Similarly, the prospect of subsequent reviews in principle could allow the agencies to forgo challenging some very "close-call" mergers that otherwise would be challenged, as mentioned by Chairman Pitofsky. ${ }^{24}$ However, it is important that this forbearance is applied only in the most limited circumstances, not as a significant change in merger enforcement policy. Replacing the current process of pre-merger 
relief with one in which mergers routinely are permitted to be consummated, subject only to subsequent enforcement during a probationary period, would be a serious policy error. Post-consummation reviews may be imperfect and remedial choices will be more limited. In addition, it may be difficult to compensate customers for the harms suffered during the interim period. The "Pyrrhic victories" of the pre-HSR world and the Evanston Northwestern consent decree make this point crystal clear. While a full-fledged policy of disgorgement and Treasury payments (as discussed below) might generate deterrence, it is better to fix the merger in advance or "just say no."

\section{The Basic Review and Modification Proposal}

The review and modification proposal would make explicit the performance goals currently implicit in any consent decree. Currently, DOJ consent decrees contain general language regarding potential modification by the court, and the Commission has the right to reopen and modify FTC orders. ${ }^{25}$ However, the court often will treat the provisions of a consent decree as contractual and limiting, and will not permit modification if those provisions fail to achieve some overarching goal of maintaining at least the same level of competition as existed before the merger or would occur absent the merger. Nor do consent decrees state this overarching goal. By making the performance goals and review process explicit, the proposed policy will overcome the current limitations on modifying consent decrees.

Under the proposal, consent decrees would include explicit review and modification provisions that would give the agency the power to petition the court to order further relief if the consent decree fails to preserve competition and protect consumer welfare. ${ }^{26}$ While I will not suggest specific language here, the consent decree would specify that modification of the remedial conditions are permitted where the purpose of the decree to preserve the degree of competition that would occur absent the merger (or, restore and preserve competition, in the case of judgments applied to consummated mergers) has not been achieved. It would be useful to flag specific issues that might suggest a potential need for subsequent modification as well as general language about preserving competition. The types of harms might be flagged, but merely as non-exclusive examples, so that the decree is not overly limiting to the agency or the court. It also might be useful for the provision to specify the burden of proof and production. In this way, the relevant conditions would be clear to the parties, and the voluntarily agreed-upon consent decree provisions could be better enforced by a court. Similar language might be used in closing statements for mergers that are cleared without challenge.

The overarching purpose of the remedial modifications would be to terminate the harm to competition, restore competitive conditions, and deprive the merged firm of the fruits of an ineffective remedy. As discussed in more detail below, the modifications could involve further divestitures or other remedies. They also could include disgorgement of supracompetitive profits. Absent another effective remedy, they might include monetary payments to the Treasury to disgorge expected future supracompetitive profits caused by the merger or oversight of future prices.

A consent decree also should require the merged firm to submit certain annual information to the agency to facilitate potential review of the success of the decree in preserving (and restoring) competition. This routinely provided information should not be excessive. For example, the agencies obviously should not be provided an annual "refresh" to the HSR second request. While more analysis of the data requirements needs to be undertaken, ordinary course data on prices, margins, quantities, and market shares of the merged firm and its competitors may well be sufficient, at least for an initial review. If the agency requires additional information for a full-fledged review, the parties should have the right to demand that the agency show the reasonableness of its requests. The requirement for these disclosures should involve a sunset provision. Merging firms should not be subject to perpetual probation.

If the merging parties dispute the need for further relief, the agency would need to defend its actions in court (or perhaps through an administrative hearing process in the case of the FTC) in an expedited proceeding. The burden of persuasion to modify the decree would be placed on the agency, but the burden should not be excessive. A burden of production would be placed on the parties because they have better access to certain information.

The Evanston Northwestern complaint was filed about four years after the merger, though the review obviously began before that date. This raises the question of the normal time lag before carrying out the typical review. On the one hand, a longer time frame means that more independent market forces could be affecting competition, which would make it more difficult to know whether the initial relief had failed or whether other factors were responsible for the outcome. A longer time frame also means that the remedy would be delayed and the remedial alternatives may become narrowed. On the other hand, it might take a significant period for the market power harms to become clear. There is also the concern that the merged firm might hold down prices until the review period has passed. Thus, the choice of time frame is an issue for further analysis. One initial proposal might be for the agencies typically to carry out the review within a 3-4 year period. It also seems reasonable to limit the agencies to only a single review. However, this comes with a significant caveat. If there is evidence that the merged firm subsequently raised prices as a result of market power flowing from or enhanced by the merger, the period might be lengthened somewhat or there might be a second review. The same caveat would apply if the parties were found to have engaged in substantial misrepresentation.

Any judicial or administrative proceeding for modification of a consent decree should be carried out on an expedited 
basis, if possible. A longer delay may reduce the ability to craft an efficient remedy and thus subject the firm to additional disgorgement and/or damages from private litigation.

\section{Alternative Remedial Modifications and Relief Provisions}

There are potential limitations involved in enforcement after the consummation of the merger. In Evanston Northwestern, the Commission did not follow the Administrative Law Judge's recommendation to require divestiture. ${ }^{27}$ It also did not order disgorgement of the supracompetitive profits. ${ }^{28}$ Instead, it simply adopted a "highly unusual" remedy of requiring the parties to engage in "independent negotiation." Unfortunately, this remedy seems impossible to monitor and instead mainly appears to be window dressing.

This remedial failure raises the issue of whether the review and modification proposal ever could lead to any real-world market benefits. It can be difficult to unscramble the eggs. However, analysis of the ex ante and ex post goals suggests that there would be substantial benefits by restoring competition and increasing deterrence through alternative modifications.

The agency might ask the court to order one or more of the following specific types of relief:

Divestitures: Divestitures are the standard remedy to preserve competition potentially lost from the merger. They also would be the first remedy considered in the postmerger review and modification process. The efficacy of divestitures would depend on the type of industry. While it might be straightforward to divest some additional grocery stores, divestiture of a plant would be impossible if, in the years following the transaction, the merged firm replaced two pre-merger factories with a single, larger factory.

- Other Structural and Behavioral Remedies: In the situation where divestitures are not possible or are highly inefficient, the modification remedy might involve licensing of intellectual property rights, technology, or know-how at zero or below-market rates. Customers may be given the option to terminate existing contracts early in order to reduce barriers to entry. If the merging firm faces a small fraction of captive customers that have been targeted for price increases while most other customers are more mobile and obtain lower prices, then it might be feasible and efficient to mandate contractual constraints on price differentials. Or, it might be efficient to prohibit contractual or unilateral restraints on resale by non-captive customers. ${ }^{29}$

Divestitures and Remedies in Other Markets: If divestitures or other remedies in the harmed market are not possible or are highly inefficient, the remedy might entail divestitures or other remedies designed to increase competition in other markets in which the merged firm competes and has market power. It would be preferable for the remedies to target other products purchased by the same consumers harmed by the merger. While this involves some cross-market balancing that is not normally done for mergers, the difference here is that the fear of such remedies could have beneficial deterrence effects on the merged firm regardless of which group of consumers gain the benefits. ${ }^{30}$

Disgorgement: While disgorgement of overcharges flowing from supracompetitive prices does not eliminate market power, the fear of disgorgement can deter its exercise. Thus, if the merged firm fears that the agency would be able to prove that the merger raised prices, relative to the but-for world, that fear could deter post-merger price increases. Fear of private treble damages actions might have similar deterrence effects. If these penalties are not certain, or if not all mergers are reviewed, the deterrence benefits will be more limited, which suggests that the policy should be more aggressive when harm is detected. In addition, the fact that the policy likely would involve a single post-merger review conducted within a few years after the merger is consummated raises a separate concern that the fear of disgorgement might only deter price increases during this interim period.

- Payments to the Treasury: Suppose that the post-merger review shows that the merger provided the firm with durable market power that cannot be effectively remedied ex post. In that case, the agency might petition the court to order the merged firm to make monetary payments to the Treasury to disgorge the net present value of future profits accruing from the likely exercise of market power caused by the merger. These payments would not deter those future price increases, of course. However, the anticipation of having to make such payments could deter merging firms from undertaking the very conduct that would lead to these payments being required.

- Ongoing Oversight of Prices: Oversight of prices can be a remedy of last resort as a substitute for the monetary payments to the Treasury. If deterrence fails and the agency makes a dramatic error of clearing a merger that creates durable monopoly power that cannot be otherwise remedied, society may be left with only two choices: (1) have a court (or regulatory agency) monitor and regulate the monopoly with the attendant imperfection of regulation; or (2) force consumers and society to suffer the distributional and efficiency harms inherent in monopoly (albeit while forcing the firm to disgorge the expected future supracompetitive profits with payments to the Treasury). While ongoing oversight of prices may create great discomfort for antitrust practitioners, commentators, and the regulated firms, paying monopoly prices creates great discomfort for consumers, who are entitled to protection by the antitrust laws.

\section{Potential Criticisms of the Proposal}

There are several criticisms that might be levied against the review and modification process. First, these post-merger reviews would involve more work for the agencies and more 
cost for the parties. While the costs likely would fall far short of a full HSR second request, they would not be trivial in situations where market power harms appear to have occurred. For this same reason, not all mergers would be reviewed in detail and detection of remedial failure would necessarily be imperfect. However, this does not seem to be a good policy reason to abandon the proposal. The bang-per-buck in terms of market correction and deterrence likely would be high.

Second, the available remedies available after the eggs have been scrambled may be more limited than those that could have been mandated in advance. However, as already discussed, certain divestitures and other remedies will remain possible. In addition, the fear of monetary sanctions and other corrective actions can serve to deter anticompetitive behavior by merged firms and anticompetitive mergers.

Third, the post-merger review raises a potential "false positive" error cost concern. The review might erroneously attribute adverse competitive effects to the merger and would lead the court to order additional relief. If this is a significant possibility, the fear of such erroneous remedies might deter the merged firm from engaging in certain procompetitive conduct. $^{31}$

However, this concern about over-deterrence comes with several significant caveats. For one thing, it is well known in the law and economics literature that both false positive and false negative errors tend to lead to under-deterrence, not over-deterrence. ${ }^{32}$ In addition, there is less (if any) over-deterrence concern for certain types of conduct. For example, suppose that the merged firm is concerned that it will face the prospect of additional relief if it leads or follows consciously parallel, oligopolistic price increases after the merger. (While such oligopoly pricing does not violate Section 1, a merger that facilitates more successful oligopoly pricing can violate Section 7.) That deterrence actually would increase consumer welfare. Moreover, deterring oligopolistic price increases that would have occurred even absent the merger would not cause social harm. The same consumer benefits would accrue to price increases forgone in response to demand increases when prices initially are supracompetitive and variable costs are constant.

Price increases also could have been caused by changes in demand or costs or other exogenous supply factors not related to the merger. The merged firm may fear that this conduct might be falsely criticized as the exercise of harmful market power flowing from the merger. Similarly, the merged firm contemplating a quality increase that would raise nominal prices, while reducing quality-adjusted prices, might fear that the agency would undervalue or even ignore the quality increase, and thereby treat the conduct as an exercise of market power.

This source of error and over-deterrence does raise a caution. It means that the agencies will need to take care in carrying out their reviews. It is not enough simply to evaluate the change in nominal prices since the merger. The agency must evaluate quality-adjusted prices as well as nominal price increases and the resulting impact on output. The agency similarly must determine the prices relative to those that would have occurred absent the merger. However, this type of comparison is within the competence of the agencies and the courts to evaluate. It therefore does not seem like a sufficient reason to give the firm a free pass after settling the case with a consent decree.

Finally, this latter discussion might lead to a criticism that the proposal is demanding a zero failure rate for merger consent decrees. That is not the case. While the agencies certainly should strive for perfection, that outcome is not possible in an uncertain world, even with this modification process. The modification process will face the remedial constraints detailed here, as well as informational constraints. Instead, the goal and benefits of the proposal are to lead to improved outcomes and deterrence. In addition, by reviewing the efficacy of consent decrees in this process, it is likely that the design of future consent decrees also can be improved. While this will be more work for the agencies, that extra work is necessary. Leaving in place flawed consent decrees harms consumers and competition and compromises the integrity and public perception of the merger enforcement process.

\section{Conclusion}

Legislation is not required to adopt this review and modification proposal. All that is required is a will by the agencies to improve merger enforcement policy. For a merger settled by consent decree, the agencies can insist on including a review and modification provision in the consent decrees. In a case in which the merging parties "litigate the fix" in court and prevail, it also would be natural for the court to include a review and modification provision in its order.

However the policy is implemented, using review and modification provisions in merger enforcement makes economic sense. As emphasized above, consumers currently bear the entire downside risk. Merging firms have little incentive to avoid over-reaching claims during the HSR review. The use of post-merger reviews and consent decree modification provisions can mitigate these concerns. Asking the merging firms to "put their money where their mouth is" can both partially insure consumers against the downside risk and facilitate a more efficient merger enforcement process.

\footnotetext{
1 This proposal was discussed on a panel at the ABA Antitrust Section Spring meeting, April 6, 2016. I would like to thank Mark Angland, Jonathan Baker, David Balto, Steven Calkins, Brian Facey, Richard Gilbert, Kathryn Fenton, Andrew Gavil, William Kovacic, John Kwoka, Roger Noll, Steve Ross, Fiona Scott Morton, Steven Sunshine, David Vladeck, and the panel participants (John Harkrider, James Nichols, Barry Nigro, and Paula Render) for helpful comments on the proposal.

2 See Bob Dylan, She Belongs to Me (1965).

3 Opinion of the Commission, Evanston Northwestern Healthcare Corp., FTC Docket No. 9315 (Aug. 6, 2007), https://www.ftc.gov/sites/default/files/ documents/cases/2007/08/070806opinion.pdf. For a survey of con-
} 
summated merger cases, see U.S. Submissions to OECD and Other International Competition Fora, Investigations of Consummated and Non-Notifiable Mergers (Feb. 5, 2014), https://www.ftc.gov/system/files/attachments/ us-submissions-oecd-other-international-competition-fora/consummated_ mergers_us_oecd.pdf.

4 Press Release, Fed. Trade Comm'n, Federal Trade Commission Announces Formation of Merger Litigation Task Force (Aug. 28, 2002), https://www. ftc.gov/news-events/press-releases/2002/08/federal-trade-commissionannounces-formation-merger-litigation.

5 United States v. Bazaarvoice, No. 13-cv-00133-WHO, 2014 WL 203966 (N.D. Cal. filed Jan. 8, 2014), https://www.justice.gov/atr/case-document/ file/488846/download.

${ }^{6}$ Final Judgment, United States v. Heraeus Electro-Nite Co., No. 1:14-cv00005-JEB (Apr. 7, 2014), https://www.justice.gov/atr/case-document/ file/498631/download.

7 Chicago Bridge \& Iron Co. v. FTC, 534 F.3d 410, 420 and n.2 (5th Cir. 2008).

8 This is the process for at least some non-merger consent decrees. A notable example involves the ASCAP and BMI consent decrees, which have been revisited periodically. In the most recent review in 2014, the DOJ's request for comments explicitly included questions about competitive effects. For example, they asked, "Are there provisions that are ineffective in protecting competition?" and "What, if any, modifications to the Consent Decrees would enhance competition and efficiency?" See Antitrust Division Review of ASCAP and BMI Consent Decrees 2014, https://www.justice.gov/ atr/ascap-bmi-decree-review.

9 Brian A. Facey, The Future of Looking Back: The Efficient Modeling of Subsequent Review, 44 Antitrust Bull. 519 (1999).

10 Joseph Brodley, The Economic Goals of Antitrust: Efficiency, Consumer Welfare and Technological Progress, 62 N.Y.U. L. Rev. 1020 (1987).

11 Robert Pitofsky, Chairman, Fed. Trade Comm'n, Subsequent Review: A Slightly Different Approach to Antitrust Enforcement, Address to the ABA Antitrust Section (Aug. 7, 1995). The Commission Statement concludes: "If the Commission concludes that competition is being reduced as a result of these vertical arrangements, it will seek appropriate relief against any firms engaged in anticompetitive conduct, including if necessary post-acquisition divestitures." Statement of the Commission, Eli Lilly and Co., FTC Docket No. C-3594, 120 F.T.C. 243, 254 (1995).

12 Facey, supra note 9, at 525 n.22 (citing Pennsylvania v. Providence Health Sys., Inc., No. 4: CV-94-772, 1994 WL 374424 (M.D. Pa. May 26, 1994)).

13 Hertz divested the Advantage brand in December 2012 to FNSA in a transaction financed by Macquarie. David McLaughlin, Mark Clothier \& Sara Forden, Hertz Fix in Dollar Thrifty Deal Fails as Insider Warned, BLOOMBERG (Nov. 19, 2013), http://www.bloomberg.com/news/articles/2013-1129/hertz-fix-in-dollar-thrifty-deal-fails-as-insider-warned. The FNSA CEO was fired some months later and Advantage subsequently declared bankruptcy in late 2013. Id. The Advantage assets were later sold to a private equity firm, Catalyst Capital, in January 2014, which then acquired the EZ Rent-ACar chain in a transaction that closed in June 2015. Danny King, Advantage Completes E-Z Rent-A-Car Deal, Travel Weekly (June 8, 2015), http://www. travelweekly.com/Travel-News/Car-Rental-News/Advantage-completes-EZRent-A-Car-deal?ct=

14 The divestee, Haggen, declared bankruptcy and sued Albertsons for damages in September 2015. Complaint, Haggen Holdings v. Albertsons, No. 1:99-mc-09999, 2015 WL 5138125 (D. Del. Sept. 1, 2015) [hereinafter Haggen Complaint], http://media2.haggen.com.s3.amazonaws.com/ website/temp/Haggen_Albertsons-Timestamped_copy_of_complaint.pdf. In the end, the lawsuit was settled for $\$ 5.75$ million in January 2016. In April 2016, Haggen sold 29 stores in the Northwest U.S to Albertsons for $\$ 106$ million. See Ivan Cruz, Alberstons Paying 5.75 Million to Settle Haggen Lawsuit, AвASto (Jan. 26, 2016), http://abastomedia.com/en/news/ albertsons-paying-5-75-million-to-settle-haggen-lawsuit/; Associated Press, Judge OKs \$106 Million Sale of Haggen to Alberstons, WASH. Post (Mar. 29, 2016), https://www.washingtonpost.com/business/judge-oks-106-million- sale-of-haggen-to-albertsons/2016/03/29/9ec0d90a-f625-11e5-958dd038dac6e718_story.html.

15 John W. Kwoka, Jr., Does Merger Control Work? A Retrospective on U.S. Enforcement Actions and Merger Outcomes, 78 Antitrust L.J. 619, 632 (2013). The sample also included some joint ventures and airline code sharing agreements.

16 John W. Kwoka, Jr., Mergers, Merger Control and Remedies; A RetroSPective Analysis of U.S. Policy (2015).

17 Robert A. Skitol, A Harsh Report Card on the Merger Enforcement Process, ANTITRUST SOURCE (Feb. 2015), http://www.americanbar.org/content/dam/ aba/publishing/antitrust_source/feb15_skitol_review_2_11f.pdf.

18 KWoKA, supra note 16, at 155.

19 Id. at 156.

20 ld.

21 ld. at 159.

22 The FTC currently is engaged in a study that will analyze the sufficiency of remedies. Press Release, Fed. Trade Comm'n, FTC Proposes to Study Merger Remedies (Jan. 9, 2015), https://www.ftc.gov/news-events/pressreleases/2015/01/ftc-proposes-study-merger-remedies. However, it does not appear that the FTC intends to bring enforcement actions to modify consent decrees for mergers that have failed to attain their goal of preserving competition.

23 For further analysis of this issue, see Steven C. Salop, Merger Settlement and Enforcement Policy for Optimal Deterrence and Maximum Welfare, 81 Fordham L. Rev. 2647 (2013).

24 Pitofsky, supra note 11.

25 See, e.g., United States v. United Shoe Co., 391 U.S. 244, 252 (1968). For two competing approaches to consumer protection consent decrees, compare FTC v. Trudeau, 662 F.3d 947 (7th Cir. 2011), with FTC v. Garden of Life, Inc., 845 F. Supp. 2d 1328 (S.D. Fla. 2012).

26 There are some informal look-backs today. Certain firms are repeat players at the agencies. When a subsequent merger is notified, it is common for the agencies to look back at previous merger to determine whether the "promised" results were achieved. In addition, if the agency finds evidence of misrepresentation in the previous deal, they presumably could bring an enforcement action for that conduct.

27 Opinion of the Commission, Evanston Northwestern Healthcare Corp., FTC Docket No. 9315, at 5 (Aug. 6, 2007), https://www.ftc.gov/sites/default/ files/documents/cases/2007/08/070806opinion.pdf.

28 Opinion of the Commission on Remedy, Evanston Northwestern Healthcare Corp., FTC Docket No. 9315 (Apr. 28, 2008), https://www.ftc.gov/sites/ default/files/documents/cases/2008/04/080428commopiniononrem edy.pdf.

29 Where exactly to place these remedies along the structural-behavioral continuum is unclear. Most require less (if any) continued monitoring by the agency or court than would ongoing price regulation. But determining the royalty level for "below-cost" licenses even once would insert the agency or court into a price setting role.

30 Of course, competitors currently benefiting from legitimate market power in the second market might complain about the increase in competition being forced on their market.

31 In an extreme scenario, the merged firm might raise prices in order to prevent an inefficient divestee from exiting the market. However, while the divestee would not exit, the price increases themselves would attract the attention of the agency.

32 Jonathan Baker, Taking the Errors Out of "Error Cost" Analysis: What's Wrong with Antitrust's Right, 80 Antitrust L.J. 1, 6 n.19 (2015); Salop, supra note 23 , at 2669 n. 60 . 